\title{
A Novel Method for Treating Heavy Metal-Contaminated Soil: The Combined Electrokinetics and Permeable Reactive Barrier Technique
}

\author{
W. Liu ${ }^{1}$ and Y.X. Yu ${ }^{1 *}$ \\ ${ }^{1}$ School of Environment, Beijing Normal University, Beijing 100088, China
}

Received 05 November 2020; revised 21 November 2020; accepted 07 January 2021; published online 06 April 2021

\begin{abstract}
Heavy metal contamination of soil is a serious environmental problem worldwide, but the remediation methods available for heavy metal-contaminated soil have many shortcomings. A combination of the electrokinetics and permeable reactive barrier (EK$\mathrm{PRB}$ ) techniques has been developed in recent decades for remediation of contaminated soils. EK-PRB has the potential to overcome the shortcomings of existing methods and to create new opportunities for the treatment of heavy metal-contaminated soils. EK-PRB combines the advantages of each method to control the transfer of heavy metals in contaminated soils and simultaneously remove them in situ. This method has the advantages of wide applicability across soil types, high adaptability, in-situ remediation, avoidance of the generation of wastewater containing heavy metals, and facilitation of resource recovery and utilization. At present, investigations of this technique have generally been conducted at the bench scale. The PRB materials used include zero-valent iron, activated carbon, and industrial waste with reduction or adsorption capacity. The heavy metal pollutants treated include chromium, cadmium, arsenic, and copper. Much work remains to be done for the further development of this technique.
\end{abstract}

Keywords: soil contamination, heavy metal, electrokinetics, permeable reactive barrier

\section{Introduction}

Soil pollution and drought are serious environmental problems, which are serious threats to food security worldwide. Currently, a large number of sites worldwide are contaminated with heavy metals, including a large amount of agricultural land (Khalid et al., 2017; Gong et al., 2018; Duan et al. 2020). Such pollution causes major risks to the local ecosystem and human health. Heavy metal contamination of soil would do harm to soil microorganisms. The research of Aponte et al. indicated that the soil enzyme activity decreased linearly in response to the contamination of heavy metals, which would change the cycling of carbon, nitrogen, phosphorus, sulphur in soil, and thus affects the soil ecosystem. In addition, heavy metal contamination could also pose selective pressure on the soil microbes, and alters their community structures (Aponte et al., 2020; Fagnano et al., 2020; Ma et al., 2020). Plants can absorb cadmium (Cd) from contaminated soil and transport it to their various organs, while $\mathrm{Cd}$ can lead to fading of the leaves, reduced photosynthesis, growth inhibition, malnutrition, abnormal nitrogen metabolism, and other symptoms in plants (Ali et al., 2015). Furthermore, large amounts of heavy metals can accumulate in food produced from contaminated soil, potentially harming the health of consumers. Research of Cao et al. (2014) and $\mathrm{Yu}$ et al. (2016a, 2016b) indicated that many residents of

${ }^{*}$ Corresponding author. Tel.: +86-13146397345.

E-mail address: yuhe_f@sina.com (Y.X. Yu).

ISSN: 2663-6859 print/2663-6867 online

(C) 2021 ISEIS All rights reserved. doi:10.3808/jeil.202100055 polluted areas have chronic daily intakes of heavy metals that exceed acceptable levels. Large number of research has shown that heavy metals have a variety of toxic effects on humans and animals. For example, hexavalent chromium $(\mathrm{Cr}(\mathrm{VI}))$ can enter cells rapidly through the sulphate transport system, and lead to carcinogenicity and mutagenic effects by generating free radicals, forming adducts of chromium and DNA and inducing Chromosomal Breakage (Zhitkovich, 2011). Therefore, it is essential to remediate such soils.

To date, soil remediation techniques have been based on the following concepts: (I) the isolation or transport of contaminated soil (e.g., the surface capping and soil replacement techniques), (II) making heavy metals in soil inert and reducing their mobility and biological impact (e.g. vitrification and pollutant stabilisation), and (III) activation of heavy metals and separation from soil (e.g., electrokinetic (EK) technique, soil leaching, phytoextraction, and microbial remediation) (Gong et al., 2018; Liu et al., 2018). However, these techniques have some notable deficiencies. For example, the isolation or transportation of heavy metal-contaminated soil does not remove heavy metals from the soil, and thus carries environmental risks. Making heavy metals inert can temporarily reduce the environmental risk, but the environmental conditions of the polluted soil may change significantly over time, possibly causing the inert heavy metals to be reactivated. Soil leaching is not applicable to low-permeability soils, EK technique and soil leaching transport the heavy metals into water phase and form contaminated water, phytoremediation has a long repair cycle, and microbial remediation can only alter the form of heavy metals, not separate them from 
the soil. Therefore, it is essential to develop new soil remediation techniques that address the deficiencies of existing systems.

The combined electro kinetics and permeable reactive barrier (EK-PRB) technique has been developed in recent years and offers many advantages for the remediation of heavy metalcontaminated soil. In the EK technique, an electric field is applied to the soil, causing the heavy metal to migrate directionally (Acar and Alshawabkeh, 1993; Yeung, 2011). In the permeable reactive barrier (PRB) technique, reactive materials are installed perpendicular to the direction of groundwater flow. When groundwater penetrates the reactive barrier, pollutants therein are removed through physical interactions or chemical reactions between the pollutants and the reactive material (Mena et al., 2016b). The EK technique has a wide range of applications; notably, it can be used in low-permeability soils, overcoming the shortcomings of the soil leaching technique. In addition, the EK method can control the migration of heavy metals and high adaptability can be achieved through engineering. The PRB technique can be used to remove heavy metals in situ, avoiding the generation of wastewater-containing heavy metals and thereby simplifying the remediation process. It can concentrate heavy metals in reactive barrier materials, laying the foundation for their subsequent recovery and reuse. The combination of EK and PRB takes full advantage of the benefits of each method and is a technique with great prospects for application.

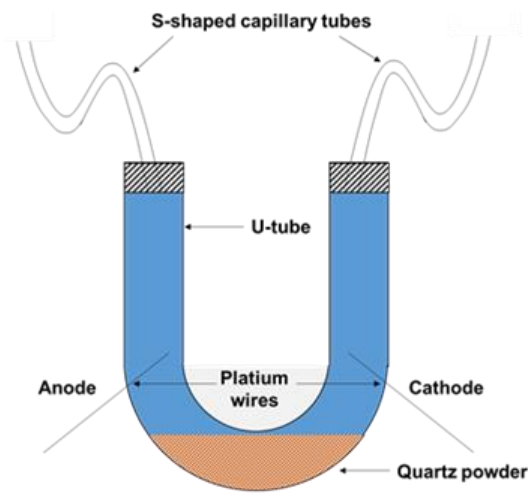

Figure 1. Schematic diagram of Reuss's experimental device.

To date, research into the EK-PRB technique remains insufficient. However, both the EK and PRB methods have been fully developed and successfully applied in engineering practice, providing a solid research basis for the EK-PRB technique (Lageman, 1993; Chung, 2009; Torres et al., 2017; Bekele et al., 2019). This technique can be expected to play an important role in the remediation of heavy metal-contaminated soils in the future. The present review briefly introduces the EK and PRB techniques and summarises the research status of the EK-PRB technique, mainly focusing on the operating conditions, pollutant removal mechanism and treatment efficiency of this method.

\section{Introduction to the EK-PRB Technique}

\subsection{EK Technique}

The EK technique has a history of more than 200 years.
The phenomenon of electroosmosis was first discovered by the Russian scientist Reuss in 1802. When Reuss electrified a Ushaped tube filled with quartz sand and water, the liquid level on the cathode side increased by $23 \mathrm{~cm}$; this process was named electroosmosis. Reuss's experimental device is shown in Figure 1 (Reuss, 1809). In the 1930s, the Indian researchers Puri and Anand applied the EK technique to remediation of saline and alkaline soils and found that EK could extract sodium ions from such soils (Puri and Anand, 1936). Since the 1980s, the technique has been used to remove harmful pollutants from soil and has been greatly improved based on theoretical and engineering considerations (Yeung, 2011). Acar et al. systematically reported the theoretical basis of the EK technique for contaminated soil remediation (Acar and Alshawabkeh, 1993). Geokinetics Inc., a company in the Netherlands, has developed engineering practices for remediation of heavy metal-contaminated soil using the EK technique (Lageman, 1993).

A schematic diagram illustrating EK remediation of contaminated soil is provided in Figure 2. Electroosmosis, electromigration, electrophoresis, and electrolysis all occur during the EK remediation of contaminated soil. Electroosmosis and electromigration are the main processes that remove pollutants from soil. Electroosmosis refers to the movement of pore water in soil under the application of an electric field. A diffusion electrical double layer forms on the contact surface between soil particles and pore water. Generally, the surface of the soil particle has a surplus negative charge, while the contact surface of the pore water has a surplus positive charge. Under an electric field, the pore water moves relative to soil particles, flowing from the anode to cathode. The dissolved heavy metal ions in the pore water will be driven by the electroosmotic flow and to be removed. Electromigration refers to charged ions in pore water moving toward the opposite electrode under the influence of an electric field. Heavy metal ions will move towards opposite electrodes by electric field forces and thus be removed. Electrophoresis refers to charged colloidal particles moving toward the opposite electrode under the action of an electric field. Colloids containing heavy metals can be removed by this mechanism. Electrolysis refers to redox reactions of pore water or dissolved substances in the anode and cathode during the remediation process. The most important electrolytic reaction is the electrolysis of water, which results in the formation of oxygen and hydrogen ions at the anode, causing acidification of the anode area, as well as the generation of hydrogen and hydroxide ions at the cathode, causing alkalinisation of the cathode area (Acar and Alshawabkeh, 1993; Yeung and Gu, 2011; Guo and Huang, 2017).

The EK technique has many advantages, such as simple implementation, in-situ remediation of contaminated soil, the ability to treat multiple types of pollutants, and applicability to a wide range of soil types. In particular, the EK technique can be used for remediation of low-permeability soils. The hydraulic coefficient of such soil is very small, so seepage generated by the hydraulic gradient is insufficient to realise the removal of pollutants (Yeung, 2011; Shu et al., 2019). Techniques such as soil leaching are not suitable for this type of soil, and EK can be used instead (Weng et al., 2007; Ramírez et al., 2015; Mena 


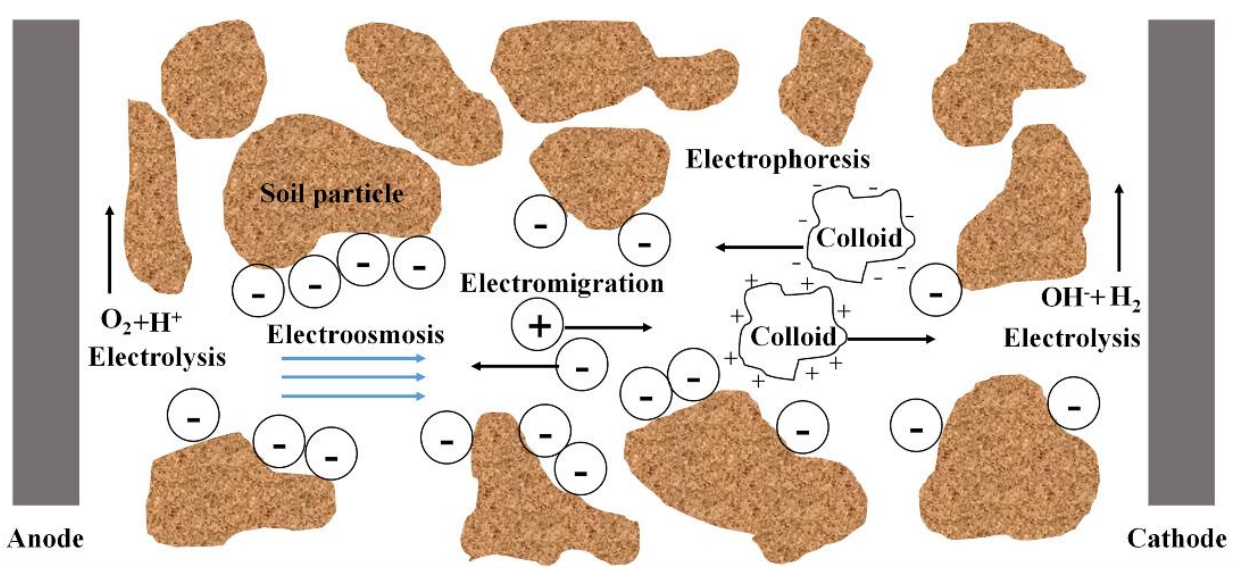

Figure 2. Schematic diagram of contaminated soil remediation with the EK technique.

et al., 2016a). However, the EK technique also has some insufficiencies. A major technical problem in the treatment of heavy metal contaminated soil by the EK technique is the alkalinization of the cathode area. During the treatment process, the water electrolysis produces hydroxide ions and hydrogen in the cathode, and the hydroxide ions migrate toward the anode under the action of electric field, resulting in the alkalinization of the cathode area, and heavy metal cations would be deposited by alkali during their migration to the cathode. At present, the regulation of cathode $\mathrm{pH}$ and the use of enhancement agents, such as ethylene diamine tetraacetic acid (EDTA), are the main method used to avoid the precipitation of heavy metal ions near the cathode. Besides, after the treatment of contaminated soil with the EK technique, pollutants in the soil are transformed into an aqueous phase. Subsequent treatment of the polluted water may complicate the remediation process and generate additional costs.

\subsection{PRB Technique}

The PRB technique was developed in the 1990s. It requires installation of reactive and permeable materials in the direction perpendicular to underground water flow as a PRB. When water passes through the PRB, redox, adsorption, precipitation, biodegradation, and other reactions occur between the barrier materials and pollutants in groundwater, thereby removing pollutants and purifying the water (O'Hannesin and Gillham, 1998; Obiri-Nyarko et al., 2014; Mena et al., 2016b). A schematic diagram showing PRB remediation of contaminated groundwater is provided in Figure 3.

Using various barrier materials, PRB can remove a variety of pollutants. Commonly used materials include zero-valentiron $(\mathrm{Fe}(0))$, activated carbon (AC), zeolite, lime, apatite, transformed red mud (TRM), and biologically reactive materials (Zijlstra et al., 2010; Vermeul et al., 2014; Ranjbar et al., 2017; Vukojević Medvidović et al., 2018; Gibert et al., 2019; Grau-Martínez et al., 2019; Huang et al., 2019). Pollutants that can be removed with the PRB technique include organic pollutants such as chlorinated hydrocarbons, polychlorinated biphenyls, polyaromatic hydrocarbons, and the benzene series (Chang and Cheng, 2006; Chen et al., 2011; Du et al., 2013, Liu et al., 2019); heavy metal and metalloid pollutants including nickel $(\mathrm{Ni})$, copper $(\mathrm{Cu})$, zinc $(\mathrm{Zn})$, lead $(\mathrm{Pb}), \mathrm{Cd}$, selenium $(\mathrm{Se})$, arsenic (As), chromium $(\mathrm{Cr})$, and mercury (Hg) (Huang et al., 2015; Robles et al., 2015; Han et al., 2016; Ranjbar et al., 2017; Medvidović et al., 2018; Huang et al., 2019; $\mathrm{Xu}$ et al., 2019); radioactive materials such as caesium-137 and strontium-90 (Vermeul et al., 2014; Torres et al., 2017); and inorganic salt pollutants such as nitrate (Li et al., 2017; Gibert et al., 2019). Therefore, PRB is a very promising technique. With further development of this technique, a greater variety of materials could be employed, and a wider range of pollutants could be removed.

PRB can remove pollutants from groundwater in situ. However, it relies on the natural hydraulic gradient of groundwater, which has poor controllability. Particularly in low-permeability soils, seepage driven by the natural hydraulic gradient is very limited, and therefore the PRB technique alone cannot achieve ideal pollutant removal (Ramírez et al., 2015). Thus, for the remediation of contaminated soil, combination of the PRB technique with other techniques may be a better choice.

\subsection{EK-PRB Technique}

For the remediation of contaminated soil, simultaneous application of the EK technique and the PRB (EK-PRB technique) can be applied. A schematic diagram of contaminated soil remediation using the EK-PRB technique is provided in Figure 4. Under the action of an electric field, soil pore water undergoes electro-seepage, which causes water-soluble pollutants to move directionally. Charged pollutant particles and colloids begin to migrate toward the opposite electrode, driven by the electric field force. The PRB is placed in the path of migrating pollutants. As water passes through the PRB, migrating pollutants are trapped in the reactive barrier through physical interactions or chemical reactions and thereby removed.

The EK-PRB technique combines the advantages of the EK and PRB techniques. Studies have shown that use of a PRB can significantly improve the removal rate of heavy metals in EK systems. An appropriate $\mathrm{PRB}$ can neutralise the $\mathrm{H}^{+}$and $\mathrm{OH}^{-}$ ions generated during the EK process, thus avoiding excessive soil acidification or alkalinisation. The EK-PRB technique has 


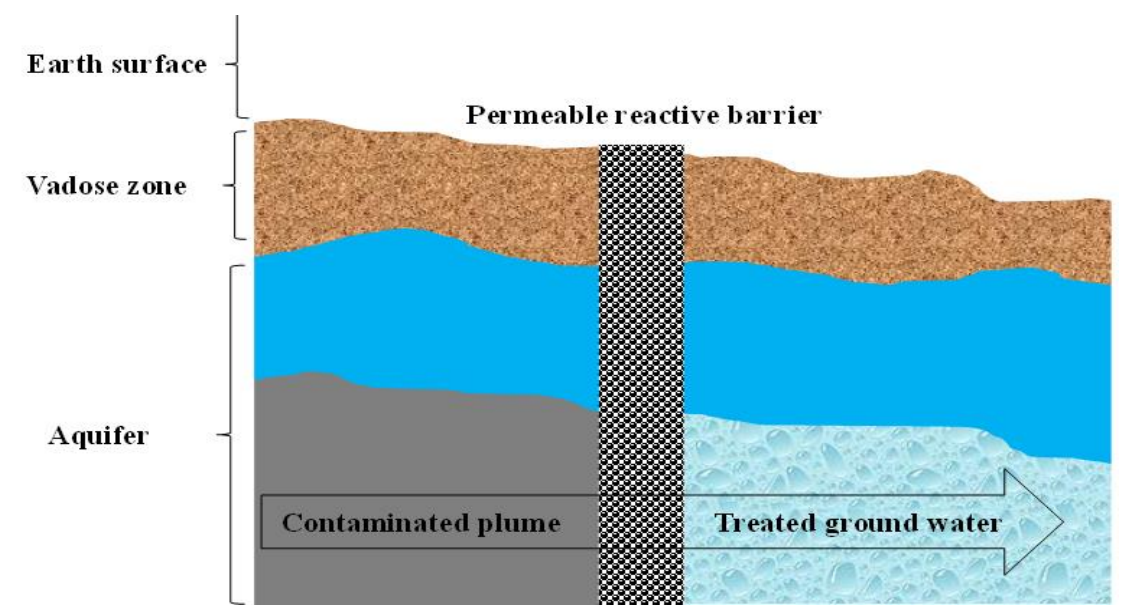

Figure 3. Schematic diagram of contaminated groundwater remediation with the PRB technique.

a wide range of applications and is suitable for a variety of soil types, especially low-permeability soil, where it overcomes the deficiencies of the soil leaching technique. This method has high adaptability, as the direction and rate of pollutant migration can be manipulated by adjusting the electric field intensity or other operating parameters. It is suitable for in-situ soil remediation, avoiding large-scale soil excavation and reducing construction costs. In addition, the PRB can remove pollutants in situ, avoid their transfer to the water phase (which creates wastewater), and simplifies the subsequent treatment process. Some pollutants, such as heavy metals, are also important resources, and the EKPRB technique can concentrate these pollutants in PRB materials. After soil remediation, appropriate technologies can be used to extract and recycle the heavy metals. This process is economically advantageous and offsets the cost of remediation; furthermore, it can promote the resource recycling and alleviate resource shortages.

\section{Research on the EK-PRB Technique for Heavy Metal-Contaminated Soil Remediation}

\subsection{Operating Parameters}

To date, almost all studies of heavy metal-contaminated soil remediation using the EK-PRB technique have been conducted at the laboratory bench scale. A schematic diagram of a typical lab-scale EK-PRB reactor is provided in Figure 5. The operating parameters of the EK-PRB techniques used in recent research are summarised in Table 1. Most contaminated soils used in these studies were artificially spiked kaolin or soil samples, while only few studies have used real heavy metal-contaminated soils. The target pollutants of previous research include $\mathrm{Cr}, \mathrm{As}, \mathrm{Cd}, \mathrm{Cu}$ and other heavy metals, among which $\mathrm{Cr}$ has been studied most extensively. The operating parameters for EK are generally a potential gradient of $1.0 \sim 3.0 \mathrm{~V} / \mathrm{cm}$, with 1.0 $\mathrm{V} / \mathrm{cm}$ being most common, and a run time of a few to a dozen days. During the treatment process, enhancement agents are generally used as the processing fluid to promote desorption of pollutants and to improve their solubility and migration ability (Yeung and $\mathrm{Gu}, 2011$ ). The enhancement agents commonly used include acidic or alkaline substances to adjust the $\mathrm{pH}$ of the electrode chamber such as nitric acid, sodium hydroxide and phosphate buffer, surfactants such as sodium dodecyl sulfonate, and chelating agents such as citric acid and EDTA. To study the influence of groundwater as a processing fluid on treatment efficacy in real engineering practice, Weng et al. used simulated groundwater prepared in the laboratory as the processing fluid, while Yuan et al. collected local groundwater as the processing fluid in their research (Weng et al., 2006, 2007; Yuan and Chiang, 2007; Yuan et al., 2009). Based on the nature of heavy metal elements such as $\mathrm{Cr}$, As, and Cd, the PRB materials commonly used include reductive metal materials such as $\mathrm{Fe}(0)$ and magnetite, as well as adsorption materials with large specific surface areas such as AC, hydrocalumite (CaAl-LDH), and TRM (De Gioannis et al., 2008; Ma et al., 2010; Suzuki et al., 2014; $\mathrm{Xu}$ et al., 2016). The installation location of the PRB is determined according to the direction of pollutant migration. For example, $\mathrm{Cr}(\mathrm{VI})$ in the soil is generally in the form of $\mathrm{Cr}_{2} \mathrm{O}_{7}{ }^{2-}$ and $\mathrm{CrO}_{4}{ }^{2-}$, which migrate toward the anode during EK treatment, and therefore the PRB is usually located near the anode (Suzuki et al., 2014; Xu et al., 2016). However, heavy metals such as $\mathrm{Cu}$ generally occur in the form of cations, which migrate toward the cathode during the treatment process. Therefore, the PRB is usually located near the cathode when those metals are targeted (Zhao et al., 2016).

\subsection{Mechanism of the EK-PRB Technique}

During the EK-PRB remediation process, heavy metal elements in the soil are driven by EK processes to the PRB, and then concentrated in the PRB through reactions with it. Recent research has focused on the combination of the EK technique with reductive metal PRB and with adsorptive PRB for remediation of heavy metal-contaminated soil.

\subsubsection{Combination of EK and Reductive Metal PRB}

Heavy metal pollutants can be removed through redox reactions with the reductive metal barrier of the PRB. When the heavy metal ions in contaminated soil migrate to PRB, reduc- 


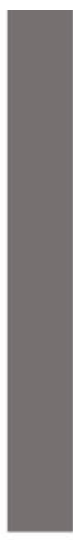

Anode

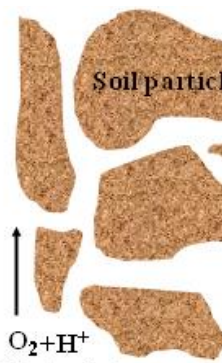

Electrolysis

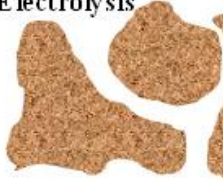

Cationic pollutants

electromigration

\section{le}

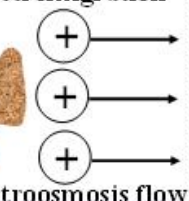

Electroosmosis flow .

Electrophoresis

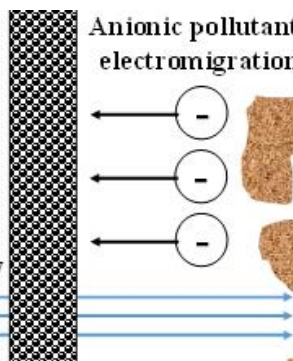

Anionic pollutants

electromigr ation

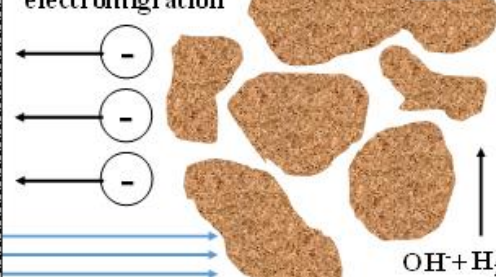

Electrophoresis

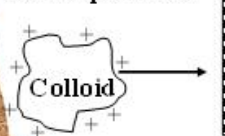

Permeable reactive barrier

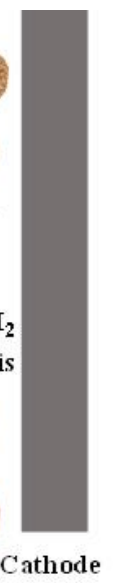

Cathode

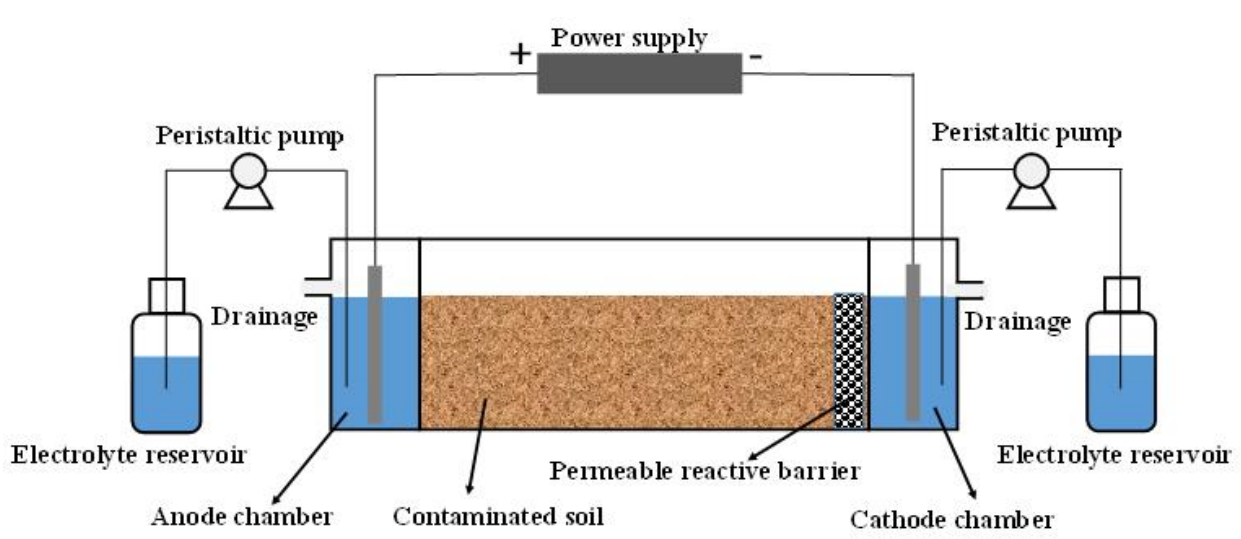

Figure 5. Schematic diagram of typical lab-scale EK-PRB reactor.

tive metal in the PRB will reduce the ions into low-valence metal ions or zero-valent metals, and then fixed in the PRB through precipitation, adsorption and other ways. Reductive metal materials mainly include $\mathrm{Fe}(0)$ and magnetite. Among others, $\mathrm{Fe}(0)$ is the most widely used material (Weng et al., 2007; Cang et al., 2009; Shariatmadari et al., 2009; Suzuki et al., 2012, 2014). Cr is the most frequently studied pollutant, and it occurs mainly in two valence states in soil: trivalent chromium $(\mathrm{Cr}(\mathrm{III}))$ and $\mathrm{Cr}(\mathrm{VI}) . \mathrm{Cr}(\mathrm{III})$ has weak migration ability and low toxicity in soil, while $\mathrm{Cr}$ (VI) has strong migration ability and high toxicity. Therefore, $\mathrm{Cr}(\mathrm{VI})$ removal is more important for remediation research (Weng et al., 2007; Cang et al., 2009). Cr(VI) exists primarily in the forms of $\mathrm{Cr}_{2} \mathrm{O}_{7}{ }^{2-}$ and $\mathrm{CrO}_{4}{ }^{2-}$. In the process of $\mathrm{Cr}-$ contaminated soil treatment using the EK-PRB technique, $\mathrm{Cr}$ containing oxysalts have negative charges and migrate to the anode. An $\mathrm{Fe}(0) \mathrm{PRB}$ is generally installed at the anode, and $\mathrm{Cr}$ driven by the electric field is transferred to the PRB. Then, these ions are reduced to $\mathrm{Cr}^{3+}$ by $\mathrm{Fe}(0)$. At the same time, $\mathrm{Fe}(0)$ is oxidised to $\mathrm{Fe}^{3+}$. The $\mathrm{Cr}^{3+}$ and $\mathrm{Fe}^{3+}$ react with $\mathrm{OH}^{-}$formed at the cathode, leading to co-precipitation of $\mathrm{Cr}(\mathrm{OH})_{3}$ and $\mathrm{Fe}(\mathrm{OH})_{3}$ and immobilisation of $\mathrm{Cr}$ in the PRB. The chemical equations of this process are presented as chemical Equations (1) and (2) (Weng et al., 2007; Cang et al., 2009; Shariatmadari et al., 2009). When the EK technique and $\mathrm{Fe}(0) \mathrm{PRB}$ are used to treat $\mathrm{Cr}$ - contaminated soil, $\mathrm{H}^{+}$generated at the anode will migrate into the $\mathrm{PRB}$ and react with $\mathrm{Fe}(0)$ to generate $\mathrm{Fe}^{2+}$. Under the action of the electric field, the $\mathrm{Fe}^{2+}$ will migrate into the soil and react with $\mathrm{Cr}(\mathrm{VI})$, leading to the formation of $\mathrm{Cr}(\mathrm{III})$ precipitate and preventing the removal of $\mathrm{Cr}$ from the soil. Suzuki et al. showed that adoption of $\mathrm{Fe}_{3} \mathrm{O}_{4}$ as the PRB can effectively prevent the diffusion of $\mathrm{Fe}^{2+}$ and the reduction of $\mathrm{Cr}(\mathrm{VI})$ in soil (Suzuki et al., 2014). The Fe(0) PRB can also effectively reduce levels of $\mathrm{Cd}, \mathrm{Ni}, \mathrm{Pb}, \mathrm{Cu}$ and other heavy metal ions, and significantly improve their stability. In the process of EK-PRB remediation, relative to the zeolite PRB, unstable forms of the four heavy metals fixed in the barrier materials decreased by $61,60,61$, and $57 \%$, respectively, in a zeolite/Fe(0) iron PRB (Ma et al., 2012):

$$
\begin{aligned}
& 2 \mathrm{Fe}+\mathrm{Cr}_{2} \mathrm{O}_{7}^{2-}+7 \mathrm{H}_{2} \mathrm{O} \rightarrow \\
& 2 \mathrm{Cr}(\mathrm{OH})_{3} \downarrow+2 \mathrm{Fe}(\mathrm{OH})_{3} \downarrow+2 \mathrm{OH}^{-} \\
& \mathrm{Fe}+\mathrm{CrO}_{4}{ }^{2-}+4 \mathrm{H}_{2} \mathrm{O} \rightarrow \\
& \mathrm{Cr}(\mathrm{OH})_{3} \downarrow+\mathrm{Fe}(\mathrm{OH})_{3} \downarrow+2 \mathrm{OH}^{-}
\end{aligned}
$$

\subsubsection{Combination of EK and Adsorptive PRB}

In the EK-adsorptive PRB technique, heavy metal pollu- 
tants are removed through adsorption. Adsorption materials include AC, CaAl-LDH, TRM and zeolite (De Gioannis et al., 2008; Xu et al., 2016; Zhao et al., 2016; Xu et al., 2017, 2019; Yu et al., 2019). AC has an extremely large specific surface area and removes heavy metal elements that migrate to its surface through adsorption. It carries a number of advantages, such as wide availability and low cost, which makes it the most promising adsorption material for engineering applications. Ma et al. used activated bamboo charcoal as PRB material to treat soil artificially spiked with $\mathrm{Cd}$. When the polarity-reversal intervals was $24 \mathrm{~h}$, the Cd removal rate was $75.97 \%$ after continuous remediation for 10.5 days (Ma et al., 2010). Gong et al. used AC to treat soil artificially spiked with $\mathrm{Cr}(\mathrm{VI})$, and the removal rate of Cr was $99.45 \%$, being $5.87 \%$ higher than that of EK technique, at the same energy utilization rate (Gong et al., 2019). In recent years, research has shown that layered double hydroxides (LDH) have good adsorption abilities for $\mathrm{Cr}$-containing oxysalts. Dai et al. showed that the adsorption capacity of calcium aluminate hydrate for Cr-containing aqueous solution can reach $1.3 \sim 1.4$ $\mathrm{mmol} \mathrm{Cr}(\mathrm{VI}) / \mathrm{g}$ (Dai et al., 2009). Xu et al. carried out a series of experiments using CaAl-LDH as the PRB material, achieving good results for the removal of $\mathrm{Cr}$ from contaminated soil. The highest removal rate of total $\mathrm{Cr}$ was $69.34 \%$ (Xu et al., 2016, 2017, 2019). Red mud (RM) is a corrosive residue produced during bauxite refining. It can be transformed using calcium chloride and magnesium chloride brine. TRM has good acid buffer capacity and can enrich metal pollutants through adsorption (De Gioannis et al., 2008; Cappai et al., 2012). De Gioannis et al. used TRM as PRB material to treat Cr contaminated kaolin, and the removal rate of total $\mathrm{Cr}$ was $93 \%$ and $57 \%$ of EK-PRB technique and EK technique respectively (De Gioannis et al., 2008). In addition, when $\mathrm{Fe}(0)$ is used as a PRB material, an adsorptive process also occurs. For example, in a study using $\mathrm{Fe}(0) \mathrm{PRB}$ to remove As from soil, adsorption and precipitation were the main mechanisms of As removal (Yuan and Chiang, 2007).

\subsection{Treatment Efficiency}

Compared to a system without a reactive barrier, the removal rate of heavy metals with the EK-PRB system was improved. Weng et al. reported $\mathrm{Cr}(\mathrm{VI})$ and total $\mathrm{Cr}$ removal rates of 78 and $28 \%$, respectively, under conditions without a PRB, which improved to $100 \%$ and $60 \sim 71 \%$, respectively, with a PRB (Weng et al., 2006). Xu et al. remediated $\mathrm{Cr}(\mathrm{VI})$-contaminated soil via the EK-PRB technique with a CaAl-LDH PRB. The results showed that the removal rates of $\mathrm{Cr}(\mathrm{VI})$ after $120 \mathrm{~h}$ of treatment with the EK-PRB system and EK system were 96 and $86 \%$, respectively, and the total $\mathrm{Cr}$ removal rates were 69 and $41 \%$, respectively (Xu et al., 2017).

Soil is a complex matrix. For different types of soils and pollutants, it is difficult to achieve consistent removal efficiency of heavy metal contaminants with the EK-PRB technique. The treatment efficiency of EK-PRB is related to soil properties, pollutant properties, and operating conditions. Huang et al. used the AC-supported $\mathrm{Fe}(\mathrm{II})$ and nanoscale $\mathrm{Fe}(0)$ as $\mathrm{PRB}$ materials to treat artificially $\mathrm{Se}(\mathrm{IV})$-spiked soil. The $\mathrm{Se}(\mathrm{IV})$ removal rate was $69 \sim 93 \%$ under different process conditions (Huang et al.,
2019). Shariatmadari et al. used nano-grade Fe(0) as a PRB material for treating clay contaminated with a low concentration of $\mathrm{Cr}(\mathrm{VI})$. The removal rate of $\mathrm{Cr}(\mathrm{VI})$ was $76 \sim 89 \%$, and the removal efficiency of total $\mathrm{Cr}$ was $18 \sim 42 \%$ (Shariatmadari et al., 2009). Han et al. used carbonised food waste as a PRB to remove $\mathrm{Cu}$ from contaminated soil and reported removal efficiencies of $53 \sim 85 \%$ (Han et al., 2010). Therefore, when applying the EK-PRB technique to practical projects, the barrier materials for the PRB and technical operation parameters should be selected according to the specific properties of the soil and the pollutants to achieve high treatment efficiency. At present, predicting the treatment efficiency of this technique based on theoretical considerations is difficult. Therefore, prior to application to engineering practice, laboratory simulations should be used to explore experimental parameters and provide reference data for subsequent project operations.

\section{Future Directions of EK-PRB Research}

\subsection{Insufficiencies}

The EK-PRB technique is still in its early stages and has not been sufficiently developed. Current research into this technique is insufficient for several reasons. First, most soils treated in previous studies have been artificially spiked with contaminants. The forms and distributions of heavy metals in these soils are likely to differ from those of real contaminated soils. Second, research on pollutant removal processes remains at the level of describing removal phenomena. Insufficient research has been conducted on pollutant removal mechanisms, and mathematical modelling of the process has not been reported to date. Finally, most research has been conducted at the bench scale, which differs greatly from engineering applications.

\subsection{Research Directions}

In the future, much research into the EK-PRB technique remains to be done. (I) Studies of remediation of real contaminated soil using the EK-PRB technique should be conducted. (II) The mechanism of the EK-PRB technique should be studied and mathematical models describing the processes of pollutant migration and transformation should be established. (III) A pilot study with engineering applications should be conducted. (IV) Efficient PRB materials should be continually developed to improve the fixation of heavy metals. (V) Research should be conducted into ways to exploit reactive industrial wastes as PRB materials in order to reduce waste discharge and promote recycling. (VI) Techniques for the recovery of heavy metals enriched in barrier materials should be explored to utilise these heavy metal resources.

\section{Conclusions}

The EK-PRB technique combines the advantages of the EK and PRB techniques, achieving heavy metal pollutant migration control in soil with simultaneous in situ removal. This technology has a wide range of applications, high adaptability, and is suitable for in-situ remediation. It can remove heavy metals in situ and has the potential to support the recovery and recycling 
Table 1. Operating Parameters of EK-PRB for Heavy Metal Contaminated Soil Remediation in Recent Research

\begin{tabular}{|c|c|c|c|c|c|c|c|}
\hline \multirow[b]{2}{*}{ Target Soil } & \multirow[b]{2}{*}{ Pollutants } & \multicolumn{2}{|c|}{ EK Technoque Parameters } & \multicolumn{3}{|c|}{ PRB Technique Parameters } & \multirow[b]{2}{*}{ Reference } \\
\hline & & $\begin{array}{l}\text { Potential } \\
\text { Gradient } \\
\text { (V/cm) }\end{array}$ & Processing Fluid & $\begin{array}{l}\text { Running } \\
\text { Time (d) }\end{array}$ & Reactive Materials & Location & \\
\hline Spiked soil & $\mathrm{Cr}$ & 2.0 & $\begin{array}{l}\text { Simulated } \\
\text { groundwater }\end{array}$ & 6 & Granular $\mathrm{Fe}(0)$ & $\begin{array}{l}\text { Near anode; } \\
\text { Middle; } \\
\text { Near cathode }\end{array}$ & $\begin{array}{l}\text { (Weng et al., } \\
\text { 2006) }\end{array}$ \\
\hline Spiked soil & $\mathrm{Cr}$ & $1.0 ; 2.0$ & $\begin{array}{l}\text { Simulated } \\
\text { groundwater }\end{array}$ & $6 ; 12$ & Granular $\mathrm{Fe}(0)$ & Middle & $\begin{array}{l}\text { (Weng et al., } \\
\text { 2007) }\end{array}$ \\
\hline Spiked soil & $\mathrm{Cd}$ & 2.0 & Deionized water & $\begin{array}{l}\text { Until current } \\
<10 \mathrm{~mA} \text {. }\end{array}$ & Atomizing slag & $\begin{array}{l}\text { Electrode } \\
\text { chamber }\end{array}$ & $\begin{array}{l}\text { (Chung and } \\
\text { Lee, 2007) }\end{array}$ \\
\hline Spiked soil & As & 2.0 & $\begin{array}{l}\text { Local } \\
\text { groundwater }\end{array}$ & 5 & $\begin{array}{l}\mathrm{Fe}(0) \\
\mathrm{FeOOH}\end{array}$ & $\begin{array}{l}\text { Near anode; } \\
\text { Middle; }\end{array}$ & $\begin{array}{l}\text { (Yuan and } \\
\text { Chiang, 2007) }\end{array}$ \\
\hline Spiked soil & $\mathrm{Cr}$ & 1.0 & $\mathrm{KCl}$ solution & 5.4 & Scrap iron & Near anode & $\begin{array}{l}\text { (Zhang and } \\
\text { Sun, 2007) }\end{array}$ \\
\hline $\begin{array}{l}\text { Spiked } \\
\text { kaolin; }\end{array}$ & $\mathrm{Cr}$ & 1.0 & Deionized water & $6 ; 12$ & TRM & Near anode & $\begin{array}{l}\text { (De Gioannis } \\
\text { et al., 2008) }\end{array}$ \\
\hline Spiked soil & $\mathrm{Cr}$ & 1.0 & $\mathrm{NaCl}$ solution & 16 & $\mathrm{Fe}(0)$ & $\begin{array}{l}\text { Near anode; } \\
\text { Middle; } \\
\text { Near cathode }\end{array}$ & $\begin{array}{l}\text { (Cang et al., } \\
\text { 2009) }\end{array}$ \\
\hline $\begin{array}{l}\text { Spiked } \\
\text { clayey soil }\end{array}$ & $\mathrm{Cr}$ & 2.0 & $\begin{array}{l}\text { Purified water; } \\
\text { Phosphate buffer }\end{array}$ & 1 & Nano-sized Fe(0) & $\begin{array}{l}\text { Near cathode; } \\
\text { Middle }\end{array}$ & $\begin{array}{l}\text { (Shariatmadar } \\
\text { et al., 2009) }\end{array}$ \\
\hline Spiked soil & As & 2.0 & $\begin{array}{l}\text { Local } \\
\text { groundwater; } \\
\text { EDTA solution }\end{array}$ & 5 & $\begin{array}{l}\text { CNT; } \\
\text { CNT coated with } \\
\text { cobalt }\end{array}$ & $\begin{array}{l}\text { Near anode; } \\
\text { Middle; } \\
\text { Near cathode }\end{array}$ & $\begin{array}{l}\text { (Yuan et al., } \\
\text { 2009) }\end{array}$ \\
\hline Spiked kaolin & $\mathrm{Cu}$ & 1.0 & SDS solution & $14 \sim 20$ & $\begin{array}{l}\text { Carbonized foods } \\
\text { waste }\end{array}$ & Near cathode & $\begin{array}{l}\text { (Han et al., } \\
2010 \text { ) }\end{array}$ \\
\hline Spiked soil & $\mathrm{Cd}$ & 1.0 & $\mathrm{KNO}_{3}$ solution & 10.5 & $\begin{array}{l}\text { Activated bamboo } \\
\text { charcoal }\end{array}$ & $\begin{array}{l}\text { Near anode and } \\
\text { near cathode } \\
\text { simultaneously }\end{array}$ & $\begin{array}{l}\text { (Ma et al., } \\
\text { 2010) }\end{array}$ \\
\hline $\begin{array}{l}\text { Spiked illitic- } \\
\text { kaolinitic soil }\end{array}$ & $\mathrm{Cr} ; \mathrm{As}$ & 1.0 & Deionized water & $6 ; 12$ & TRM & Near anode & $\begin{array}{l}\text { (Cappai et al., } \\
\text { 2012) }\end{array}$ \\
\hline Spiked kaolin & $\mathrm{Cr}$ & 0.74 & $\begin{array}{l}\text { Anode: } \mathrm{NaOH} \\
\text { solution } \\
\text { Cathode: } \mathrm{HNO}_{3} \\
\text { solution }\end{array}$ & $9 ; 18$ & $\begin{array}{l}\text { AC + Bacteria } \\
\text { Zeolite + Bacteria }\end{array}$ & Near anode & $\begin{array}{l}\text { (Fonseca et } \\
\text { al., 2012) }\end{array}$ \\
\hline Spiked soil & $\mathrm{Cr}$ & 2.0 & - & 5 & $\begin{array}{l}\text { Anode: Iron powder; } \\
\text { Zeolite; Iron powder } \\
\text { + zeolite } \\
\text { Cathode: Acidified } \\
\text { zeolite }\end{array}$ & $\begin{array}{l}\text { Electrode } \\
\text { chamber }\end{array}$ & $\begin{array}{l}\text { (Fu et al., } \\
2012 \text { ) }\end{array}$ \\
\hline Spiked soil & $\begin{array}{l}\mathrm{Cd} ; \mathrm{Ni} \\
\mathrm{Pb} ; \mathrm{Cu}\end{array}$ & 1.5 & - & 10 & $\begin{array}{l}\text { Anode: Acidified } \\
\text { zeolite } \\
\text { Cathode: Iron } \\
\text { powder; Zeolite; Iron } \\
\text { powder + zeolite }\end{array}$ & $\begin{array}{l}\text { Electrode } \\
\text { chamber }\end{array}$ & $\begin{array}{l}\text { (Ma et al., } \\
\text { 2012) }\end{array}$ \\
\hline Spiked kaolin & $\mathrm{Cr}$ & 1.0 & $\mathrm{NaNO}_{3}$ solution & 5 & $\begin{array}{l}\mathrm{Fe}(0) \\
\mathrm{Fe}_{3} \mathrm{O}_{4}\end{array}$ & Near anode & $\begin{array}{l}\text { (Suzuki et al., } \\
\text { 2014) }\end{array}$ \\
\hline Spiked soil & $\mathrm{Cr}$ & 1.2 & - & 3 & CaAl-LDH & Near anode & $\begin{array}{l}\text { (Xu et al., } \\
\text { 2016) }\end{array}$ \\
\hline Spiked kaolin & $\mathrm{Cu}$ & 1.0 & $\begin{array}{l}\text { Anode: } \mathrm{NaNO}_{3} \\
\text { solution } \\
\text { Cathode: Citric } \\
\text { acid buffer }\end{array}$ & 4 & $\mathrm{AC}$ & Near cathode & $\begin{array}{l}\text { (Zhao et al., } \\
\text { 2016) }\end{array}$ \\
\hline Spiked soil & $\mathrm{Cr}$ & $\begin{array}{l}1.0 ; 1.5 \\
2.0\end{array}$ & 一 & $3 ; 5$ & CaAl-LDH & Near anode & $\begin{array}{l}\text { (Xu et al., } \\
\text { 2017) }\end{array}$ \\
\hline $\begin{array}{l}\text { Contaminated } \\
\text { soil from } \\
\text { mining area }\end{array}$ & $\mathrm{Cr} ; \mathrm{As}$ & 1.0 & - & 4 & CaAl-LDH & Anode chamber & $\begin{array}{l}\text { (Xu et al., } \\
2019 \text { ) }\end{array}$ \\
\hline
\end{tabular}


Continued

\begin{tabular}{|c|c|c|c|c|c|c|c|}
\hline \multirow[b]{2}{*}{ Target Soil } & \multirow[b]{2}{*}{ Pollutants } & \multicolumn{3}{|c|}{ EK Technoque Parameters } & \multicolumn{2}{|c|}{ PRB Technique Parameters } & \multirow[b]{2}{*}{ Reference } \\
\hline & & $\begin{array}{l}\text { Potential } \\
\text { Gradient }(\mathrm{V} / \mathrm{cm})\end{array}$ & $\begin{array}{l}\text { Processing } \\
\text { Fluid }\end{array}$ & $\begin{array}{l}\text { Running Time } \\
\text { (d) }\end{array}$ & $\begin{array}{l}\text { Reactive } \\
\text { Materials } \\
\end{array}$ & Location & \\
\hline $\begin{array}{l}\text { Spiked } \\
\text { kaolin/gypsum }\end{array}$ & $\mathrm{Se}$ & $0.5 ; 1.0 ; 1.5 ; 2.0$ & $\begin{array}{l}\text { Phosphate } \\
\text { buffer }\end{array}$ & $3 ; 6 ; 9 ; 12$ & $\begin{array}{l}\text { AC-supported } \\
\mathrm{Fe}(0)+\mathrm{AC}- \\
\text { supported } \mathrm{Fe}(\mathrm{II})\end{array}$ & $\begin{array}{l}\text { Near anode; } \\
\text { Lasagna form }\end{array}$ & $\begin{array}{l}\text { (Huang et } \\
\text { al., 2019) }\end{array}$ \\
\hline $\begin{array}{l}\text { Contaminated } \\
\text { soil from an } \\
\text { industrial park }\end{array}$ & $\mathrm{Cr}$ & $1.5 ; 2.0 ; 2.5$ & $\begin{array}{l}\text { Anode: } \mathrm{KCl} \\
\text { solution } \\
\text { Cathode: } \mathrm{KCl} \\
\text { solution; DL- } \\
\text { tartaric acid } \\
\text { solution; } \\
\text { Tween } 80 \\
\text { solution; } \\
\text { Solution of } \\
\text { mixed DL- } \\
\text { tartaric acid } \\
\text { Tween } 80\end{array}$ & $4 ; 5 ; 6 ; 8$ & $\begin{array}{l}\text { Modified } \\
\text { zoelite; } \\
\text { Modified zoelite } \\
+\mathrm{Fe}(0)\end{array}$ & Near anode & $\begin{array}{l}\text { (Yu et al., } \\
\text { 2019) }\end{array}$ \\
\hline Spiked soil & $\mathrm{Cr}$ & $1.0 ; 2.0 ; 3.0$ & $\begin{array}{l}\text { Deionized } \\
\text { water }\end{array}$ & 5 & $\mathrm{AC}$ & Near anode & $\begin{array}{l}\text { (Gong et } \\
\text { al., 2019) }\end{array}$ \\
\hline
\end{tabular}

* $\mathrm{Fe}(0)$, Zero-valent iron; FeOOH, Hydrous ferric hydroxide; TRM, Transformed red mud; CNT, Carbon nanotubes; EDTA, Ethylene Diamine Tetraacetic Acid; SDS, Sodium dodecyl sulfate; AC, Activate carbon; CaAl-LDH, Hydrocalumite; Lasagna form, the soil to be remediated and permeable reactive barriers are distributed layer by layer, which is similar to Italian lasagna.

of heavy metals. Therefore, EK-PRB is a very promising remediation technique for soils contaminated with heavy metals. Currently, this technique is still in the development stage, and research into it has mainly been at the bench scale. Many deficiencies of this method remain that urgently require investigation, creating a major opportunity for future research.

Acknowledgement. This research was supported by grants from the National Natural Science Foundation of China (No. 41371466).

\section{References}

Acar, Y.B. and Alshawabkeh, A.N. (1993). Principles of electrokinetic remediation. Environmental Science \& Technology, 27(13), 26382647. https://pubs.acs.org/doi/abs/10.1021/es00049a002

Ali, E., Maodzeka, A., Hussain, N., Shamsi, I.H. and Jiang, L. (2015). The alleviation of cadmium toxicity in oilseed rape (Brassica napus) by the application of salicylic acid. Plant Growth Regulation, 75(3), 641-655. https://doi.org/10.1007/s10725-014-9966-0

Aponte, H., Meli, P., Butler, B., Paolini, J., Matus, F., Merino, C., Cornejo, P. and Kuzyakov, Y. (2020). Meta-analysis of heavy metal effects on soil enzyme activities. Science of the Total Environment, 737, 139744. https://doi.org/10.1016/j.scitotenv.2020.139744

Bekele, D.N., Du, J.H., de Freitas, L.G., Mallavarapu, M., Chadalavada, S. and Naidu, R. (2019). Actively facilitated permeable reactive barrier for remediation of TCE from a low permeability aquifer: Field application. Journal of Hydrology, 572, 592-602. https://doi.org/10.1016/j.jhydrol.2019.03.059

Cang, L., Zhou, D., Wu, D. and Alshawabkeh, A.N. (2009). Coupling electrokinetics with permeable reactive barriers of zero-valent iron for treating a chromium contaminated soil. Separation Science and Technology, 44(10), 2188-2202. https://doi.org/10.1080/01496390 902976699

Cao, S., Duan, X., Zhao, X., Ma, J., Dong, T., Huang, N., Sun, C., He, B. and Wei, F. (2014). Health risks from the exposure of children to $\mathrm{As}, \mathrm{Se}, \mathrm{Pb}$ and other heavy metals near the largest coking plant in China. Science of the Total Environment, 472, 1001-1009. https:// doi.org/10.1016/j.scitotenv.2013.11.124

Cappai, G., De Gioannis, G., Muntoni, A., Spiga, D. and Zijlstra, J.J. (2012). Combined use of a transformed red mud reactive barrier and electrokinetics for remediation of $\mathrm{Cr} / \mathrm{As}$ contaminated soil. Chemosphere, 86(4), 400-408. https://doi.org/10.1016/j.chemosphere.20 11.10 .053

Chang, J.H. and Cheng, S.F. (2006). The remediation performance of a specific electrokinetics integrated with zero-valent metals for perchloroethylene contaminated soils. Journal of Hazardous Materials, B131, 153-162. https://doi.org/10.1016/j.jhazmat.2005.09.026

Chen, L., Liu, F., Liu, Y., Dong, H. and Colberg, P.J. (2011). Benzene and toluene biodegradation down gradient of a zero-valent iron permeable reactive barrier. Journal of Hazardous Materials, 188, 110115. https://doi.org/10.1016/j.jhazmat.2011.01.076

Chung, H.I. (2009). Field applications on electrokinetic reactive pile technology for removal of $\mathrm{Cu}$ from in-situ and excavated soils. Separation Science and Technology, 44(10), 2341-2353. https://doi. org/10.1080/01496390902983687

Chung, H.I. and Lee, M. (2007). A new method for remedial treatment of contaminated clayey soils by electrokinetics coupled with permeable reactive barriers. Electrochimica Acta, 52(10), 3427-3431. https://doi.org/10.1016/j.electacta.2006.08.074

Dai, Y., Qian, G., Cao, Y., Chi, Y., Xu, Y., Zhou, J., Liu, Q., Xu, Z.P. and Qiao, S. (2009). Effective removal and fixation of $\mathrm{Cr}(\mathrm{VI})$ from aqueous solution with Friedel's salt. Journal of Hazardous Materials, 170, 1086-1092. https://doi.org/10.1016/j.jhazmat.2009.05.070

De Gioannis, G., Muntoni, A., Ruggeri, R. and Zijlstra, J.J. (2008). Chromate adsorption in a transformed red mud permeable reactive barrier using electrokinesis. Journal of Environmental Science and Health, Part A: Toxic/Hazardous Substances and Environmental Engineering, 43(8), 969-974. https://doi.org/10.1080/10934520801 974582

Du, J., Liu, Y.Y., Zhang, X.Q., Qiu, M.Y., Zhang, L.Y. and Fan, Y.N. (2013). Fe0/Zn0 PRB technology for the remediation of PCBs contaminated groundwater. Applied Mechanics and Materials, 295298, 1364-1367. https://doi.org/10.4028/www.scientific.net/AMM. 295-298.1364

Duan, R., Huang, G., Li, Y., Zhou, X., Ren, J. and Tian, C. (2020). Stepwise clustering future meteorological drought projection and multi-level factorial analysis under climate change: A case study of 
the Pearl River Basin, China. Environmental Research, 110368 https://doi.org/10.1016/j.envres.2020.110368

Fagnano, M., Agrelli, D., Pascale, A., Adamo, P., Fiorentino, N., Rocco, C., Pepe, O. and Ventorino, V. (2020). Copper accumulation in agricultural soils: Risks for the food chain and soil microbial populations. Science of the Total Environment, 734, 139434. https://doi. org/10.1016/j.scitotenv.2020.139434

Fonseca, B., Pazos, M., Tavares, T. and Sanroman, M.A. (2012). Removal of hexavalent chromium of contaminated soil by coupling electrokinetic remediation and permeable reactive biobarriers. Environmental Science and Pollution Research, 19(5), 1800-1808. https://doi.org/10.1007/s11356-011-0694-y

Fu, R., Liu, F., Ma, J., Zhang, C. and He, G. (2012). Remediation of Chromium(VI) contaminated soils using permeable reactive composite electrodes technology. Environmental Science, 33(1), 280285 (in Chinese).

Gibert, O., Assal, A., Devlin, H., Elliot, T. and Kalin, R.M. (2019). Performance of a field-scale biological permeable reactive barrier for in-situ remediation of nitrate-contaminated groundwater. Science of the Total Environment, 659, 211-220. https://doi.org/10.101 6/j.scitotenv.2018.12.340

Gong, W., Chen, Y., Wang, L., Han, X. and Chen, F. (2019). Remediation of chromate contaminated soil using electrokenetics-coupled activated carbon PRB. Journal of Huaqiao University (Natural Science), 40(3), 363-369. https://doi. org/10.11830/ISSN.1000-50 13.201810072

Gong, Y., Zhao, D. and Wang, Q. (2018). An overview of field-scale studies on remediation of soil contaminated with heavy metals and metalloids: Technical progress over the last decade. Water Research, 147, 440-460. https://doi.org/10.1016/j.watres.2018.10.024

Grau-Martínez, A., Torrentó, C., Carrey, R., Soler, A. and Otero, N. (2019). Isotopic evidence of nitrate degradation by a zero-valent iron permeable reactive barrier: Batch experiments and a field scale study. Journal of Hydrology, 570, 69-79. https://doi.org/10.1016/j. jhydrol.2018.12.049

Guo, S. and Huang, D. (2017) Principle and Technology of Electrokinetic Remediation of Contaminated soil. China environment publishing group, Beijing.

Han, J.G., Hong, K.K., Kim, Y.W. and Lee, J.Y. (2010). Enhanced electrokinetic $(\mathrm{E} / \mathrm{K})$ remediation on copper contaminated soil by CFW (carbonized foods waste). Journal of Hazardous Materials, 177, 530-538. https://doi.org/10.1016/j.jhazmat.2009.12.065

Han, W., Fu, F., Cheng, Z., Tang, B. and Wu, S. (2016). Studies on the optimum conditions using acid-washed zero-valent iron/aluminum mixtures in permeable reactive barriers for the removal of different heavy metal ions from wastewater. Journal of Hazardous Materials, 302, 437-446. https://doi.org/10.1016/j. jhazmat.2015. 09.041

Huang, T., Li, D., Liu, K. and Zhang, Y. (2015). Heavy metal removal from MSWI fly ash by electrokinetic remediation coupled with a permeable activated charcoal reactive barrier. Scientific Reports, 5 , 1-16. https://doi.org/10.1038/srep15412

Huang, T., Liu, L., Zhang, S. and Xu, J. (2019). Evaluation of electrokinetics coupled with a reactive barrier of activated carbon loaded with a nanoscale zero-valent iron for selenite removal from contaminated soils. Journal of Hazardous Materials, 368, 104-114. https://doi.org/10.1016/j.jhazmat.2019.01.036

Khalid, S., Shahid, M., Niazi, N.K., Murtaza, B., Bibi, I. and Dumat, C. (2017). A comparison of technologies for remediation of heavy metal contaminated soils. Journal of Geochemical Exploration, 182, 247-268. https://doi.org/10.1016/j.gexplo.2016.11.021

Lageman, R. (1993). Electroreclamation applications in the Netherlands. Environmental Science \& Technology, 27(13), 2648-2650. https://pubs.acs.org/doi/10.1021/es00049a003

Li, R., Feng, C., Xi, B., Chen, N., Jiang, Y., Zhao, Y., Li, M., Dang, Q. and Zhao, B. (2017). Nitrate removal efficiency of a mixotrophic denitrification wall for nitrate-polluted groundwater in situ remediation. Ecological Engineering, 106, 523-531. https://doi.org/ 10.1016/j.ecoleng.2017.06.010

Liu, C., Chen, X., Mack, E.E., Wang, S., Du, W., Yin, Y., Banwart, S.A. and Guo, H. (2019). Evaluating a novel permeable reactive bio-barrier to remediate PAH-contaminated groundwater. Journal of Hazardous Materials, 368, 444-451. https://doi.org/10.1016/ j.jhazmat.2019.01.069

Liu, L., Li, W., Song, W. and Guo, M. (2018). Remediation techniques for heavy metal-contaminated soils: Principles and applicability. Science of the Total Environment, 633, 206-219. https:// doi.org/10.1016/j.scitotenv.2018.03.161

Ma, J., Luo, H., Fu, R., Jiang, X., Liu, F. and Zhang, C. (2012). Electrokinetic removal of heavy metals in contaminated soil using permeable reactive composite electrodes. Environmental Pollution \& Control, 34(5), 17-23 (in Chinese).

Ma, J.W., Wang, F.Y., Huang, Z.H. and Wang, H. (2010). Simultaneous removal of 2,4-dichlorophenol and Cd from soils by electrokinetic remediation combined with activated bamboo charcoal. Journal of Hazardous Materials, 176, 715-720. https://doi.org/10. 1016/j.jhazmat.2009.11.093

Ma, Y., Wang, Y., Chen, Q., Li, Y., Guo, D., Nie, X. and Peng, X. (2020). Assessment of heavy metal pollution and the effect on bacterial community in acidic and neutral soils. Ecological Indicators, 117, 106626. https://doi.org/10.1016/j.ecolind.2020.10 6626

Mena, E., Villaseñor, J., Cañizares, P. and Rodrigo, M.A. (2016a). Influence of electric field on the remediation of polluted soil using a biobarrier assisted electro-bioremediation process. Electrochimica Acta, 190, 294-304. https://doi.org/10.1016/j.electacta.2015.12. 133

Mena, E., Villaseñor, J., Rodrigo, M.A. and Cañizares, P. (2016b). Electrokinetic remediation of soil polluted with insoluble organics using biological permeable reactive barriers: Effect of periodic polarity reversal and voltage gradient. Chemical Engineering Journal, 299, 30-36. https://doi.org/10.1016/j.cej.2016.04.049

O'Hannesin, S.F. and Gillham, R.W. (1998). Long-term performance of an in situ "Iron Wall" for remediation of VOCs. Ground Water, 36(1), 164-170. https://doi.org/10.1111/j.1745-6584.1998.tb01077.x

Obiri-Nyarko, F., Grajales-Mesa, S.J. and Malina, G. (2014). An overview of permeable reactive barriers for in situ sustainable groundwater remediation. Chemosphere, 111, 243-259. https://doi.org/10. 1016/j.chemosphere.2014.03.112

Puri, A.N. and Anand, B. (1936). Reclamation of alkali soils by electrodialysis. Soil Science, 42(1), 23-27. https://doi.org/10.1097/ 00010694-193607000-00003

Ramírez, E.M., Jiménez, C.S., Camacho, J.V., Rodrigo, M.A.R. and Cañizares, P. (2015). Feasibility of coupling permeable bio-barriers and electrokinetics for the treatment of diesel hydrocarbons polluted soils. Electrochimica Acta, 181, 192-199. https://doi.org/10.1016/j. electacta.2015.02.201

Ranjbar, E., Ghiassi, R. and Akbary, Z. (2017). Lead removal from groundwater by granular mixtures of pumice, perlite and lime using permeable reactive barriers. Water and Environment Journal, 31(1), 39-46. https://doi.org/10.1111/wej.12223

Reuss, F.F. (1809). Sur un nouveleffet de l'electricitéglavanique. Mém. Soc. Impériale Nat., Moscou2, 327-337

Robles, I., Lozano, M.J., Solís, S., Hernández, G., Paz, M.V., Olvera, M.G. and Bustos, E. (2015). Electrokinetic treatment of mercurypolluted soil facilitated by ethylenediaminetetraacetic acid coupled with a reactor with a permeable reactive barrier of iron to recover mercury (II) from water. Electrochimica Acta, 181, 68-72. https:// doi.org/10.1016/j.electacta.2015.04.099

Shariatmadari, N., Weng, C.H. and Daryaee, H. (2009). Enhancement of hexavalent chromium [Cr(VI)] remediation from clayey soils by electrokinetics coupled with a nano-sized zero-valent iron barrier. Environmental Engineering Science, 26(6), 1071-1079. http://doi. org/10.1089/ees.2008.0257 
Shu, J., Sun, X., Liu, R., Liu, Z., Wu, H., Chen, M. and Li, B. (2019). Enhanced electrokinetic remediation of manganese and ammonia nitrogen from electrolytic manganese residue using pulsed electric field in different enhancement agents. Ecotoxicology and Environ mental Safety, 171, 523-529. https://doi.org/10.1016/j.ecoenv.2019. 01.025

Suzuki, T., Kawai, K., Moribe, M. and Niinae, M. (2014). Recovery of $\mathrm{Cr}$ as $\mathrm{Cr}$ (III) from $\mathrm{Cr}$ (VI)-contaminated kaolinite clay by electrokinetics coupled with a permeable reactive barrier. Journal of Hazardous Materials, 278, 297-303. https://doi.org/10.1016/j.jhaz mat.2014.05.086

Suzuki, T., Oyama, Y., Moribe, M. and Niinae, M. (2012). An electrokinetic/Fe0 permeable reactive barrier system for the treatment of nitrate-contaminated subsurface soils. Water Research, 46(3), 772-778. https://doi.org/10.1016/j.watres.2011.11.048

Torres, E., Gómez, P., Garralón, A., Buil, B., Turrero, M.J. and Peña, J. (2017). Evaluation of the efficiency of a clay permeable reactive barrier for the remediation of groundwater contaminated with 137Cs. Procedia Earth and Planetary Science, 17, 444-447. https:// doi.org/10.1016/j.proeps.2016.12.112

Vermeul, V.R., Szecsody, J.E., Fritz, B.G., Williams, M.D., Moore, R.C. and Fruchter, J.S. (2014). An injectable apatite permeable reactive barrier for in situ 90Sr immobilization. Groundwater Monitoring \& Remediation, 34(2), 28-41. https://doi.org/10.1111/gwmr. 12055

Vukojević Medvidović, N., Nuić, I., Ugrina, M. and Trgo, M. (2018). Evaluation of natural zeolite as a material for permeable reactive barrier for remediation of zinc-contaminated groundwater based on column study. Water Air \& Soil Pollution, 229(11), 367-381. https: //doi.org/10.1007/s11270-018-4019-3

Weng, C., Lin, T.Y., Chu, S. and Yuan, C. (2006). Laboratory-scale evaluation of $\mathrm{Cr}(\mathrm{VI})$ removal from clay by electrokinetics incorporated with $\mathrm{Fe}(0)$ barrier. Practice Periodical of Hazardous, Toxic, and Radioactive Waste Management, 10(3), 171-178. https://doi. org/ 10. 1061/(ASCE)1090-025X(2006)10:3(171)

Weng, C., Lin, Y., Lin, T. and Kao, C. (2007). Enhancement of electrokinetic remediation of hyper-Cr(VI) contaminated clay by zerovalent iron. Journal of Hazardous Materials, 149, 292-302. https:// doi.org/10.1016/j.jhazmat.2007.03.076

Xu, Y., Li, J., Xia, W., Sun, Y., Qian, G. and Zhang, J. (2019). Enhanced remediation of arsenic and chromium co-contaminated soil by eletrokinetic-permeable reactive barriers with different reagents. Environmental Science \& Pollution Research, 26(4), 3392-3403. https://doi.org/10.1007/s11356-018-3842-9

Xu, Y., Xia, W., Hou, H., Zhang, J. and Qian, G. (2017). Remediation of chromium-contaminated soil by electrokinetics and electrokinetics coupled with CaAl-LDH permeable reaction barrier. Environmental Science and Pollution Research, 24(25), 20479-20486. https://doi.org/10.1007/s11356-017-9705-y
Xu, Y., Xu, X., Hou, H., Zhang, J., Zhang, D. and Qian, G. (2016). Moisture content-affected electrokinetic remediation of $\mathrm{Cr}(\mathrm{VI})$ contaminated clay by a hydrocalumite barrier. Environmental Science and Pollution Research, 23(7), 6517-6523. https://doi.org/10. 1007/s11356-015-5685-y

Yeung, A.T. (2011). Milestone developments, myths, and future directions of electrokinetic remediation. Separation and Purification Technology, 79(2), 124-132. https://doi.org/10.1016/j.seppur.2011. 01.022

Yeung, A.T. and Gu, Y.Y. (2011). A review on techniques to enhance electrochemical remediation of contaminated soils. Journal of Hazardous Materials, 195, 11-29. https://doi.org/10.1016/j.jhazmat.20 11.08.047

Yu, X., Muhammad, F., Yan, Y., Yu, L., Li, H., Huang, X., Jiao, B., $\mathrm{Lu}, \mathrm{N}$. and Li, D. (2019). Effect of chemical additives on electrokinetic remediation of Cr-contaminated soil coupled with a permeable reactive barrier. Royal Society Open Science, 6(5), 1-17. https://doi.org/10.1098/rsos.182138

Yu, Y., Li, Q., Wang, H., Wang, B., Lu, Q., Yan, Z. and Ding, A. (2016a). Exposure risk of young population to lead: A case study in Le'an River Basin in Jiangxi Province, China. Environmental Pollution, 209, 140-146. https://doi.org/10.1016/j.envpol.2015.11. 017

Yu, Y., Wang, H., Li, Q., Wang, B., Yan, Z. and Ding, A. (2016b). Exposure Risk of Rural Residents to Copper in the Le'an River Basin, Jiangxi Province, China. Science of the Total Environment, 548, 402-407. https://doi.org/10.1016/j.scitotenv.2015.11.107

Yuan, C. and Chiang, T.S. (2007). The mechanisms of arsenic removal from soil by electrokinetic process coupled with iron permeable reaction barrier. Chemosphere, 67(8), 1533-1542. https://doi.org/ 10.1016/j.chemosphere.2006.12.008

Yuan, C., Hung, C.H. and Chen, K.C. (2009). Electrokinetic remediation of arsenate spiked soil assisted by CNT-Co barrier - the effect of barrier position and processing fluid. Journal of Hazardous Materials, 171, 563-570. https://doi.org/10.1016/j.jhazmat.2009.06.059

Zhang, R. and Sun, H. (2007). Remediation of chromate contaminated soils by combined technology of electrokinetic and iron PRB. Environmental Science, 28(5), 1131-1136 (in Chinese).

Zhao, S., Fan, L., Zhou, M., Zhu, X. and Li, X. (2016). Remediation of copper contaminated kaolin by electrokinetics coupled with permeable reactive barrier. Procedia Environmental Sciences, 31, $274-$ 279. https://doi.org/10.1016/j.proenv.2016.02.036

Zhitkovich, A. (2011). Chromium in drinking water: sources, metabolism, and cancer risks. Chemical Research in Toxicology, 24(10), 1617-1629. https://doi.org/10.1021/tx200251t

Zijlstra, J.J.P., Dessì, R., Peretti, R. and Zucca, A. (2010). Treatment of percolate from metal sulfide mine tailings with a permeable reactive barrier of transformed red mud. Water Environment Re- search, 82(4), 319-327. https://doi.org/10.2175/106143009X12487 095236 432 